\title{
Pathways to Curriculum Redesign
}

\author{
Sang E Park* \\ Associate Dean for Dental Education, Harvard School of Dental Medicine, Boston, Massachusetts
}

Submission: June 18, 2021; Published: July 02, 2021

*Corresponding author: Sang E Park, Associate Dean for Dental Education, Harvard School of Dental Medicine, 188 Longwood Ave, Boston, Massachusetts

\section{Short Communication}

A dental curriculum possesses multiple layers of complexities and integrative levels of organization that are combined with sequential timeline and delivery. Introducing even a minor change in the curriculum could be viewed as a major undertaking that warrants significant amount of time, various resources, and financial commitment to support the curriculum change processes [1-5]. Redesigning of the curriculum utilizes multiple approaches that include envisioning the objectives, reviewing the contents, revising the methods, and re-evaluating the effectiveness, which could be a valuable opportunity to improve its deficiencies [611]. Harvard School of Dental Medicine (HSDM) implemented the current curriculum in August 2015 particularly regarding aspects of the dental school experience that had historically been difficult for students, such as the lack of integration between the basic science courses and clinical experiences. The reorganization of the HSDM curriculum which instituted major changes to the preclinical year, has provided opportunities to identify deficiencies and strengthen the curriculum in the redesigning process. The change was intended to improve the curriculum and the learning environment of the students by incorporating the current educational methodologies and integrating basic science and clinical dentistry throughout the entire four years, offering longitudinal continuity of cross-disciplinary learning

The curricular goal was to provide students with a core clinical education that is fully integrated across the basic, social, and clinical sciences and that serves as the broad foundation for life-long learning and to support an integrated clinical education using a multifaceted approach. This curriculum reorganization acknowledges that core basic science knowledge and skills are needed prior to the clinical years, and the richness of more advanced clinical science is best suited to students who have already had exposure to clinical experience. In the newly designed curriculum, dental core science content was shifted to integrate the core sciences with earlier patient-centered care. The expectation is that having studied in a clinical context, students will be more engaged and prepared for learning, and will find the advanced dental courses more manageable, relevant, and compelling. At the same time, the reorganized curriculum should energize clinical faculty, as they encounter a cohort of students more receptive to exploration and better prepared to appreciate the relevancy of an advanced dental curriculum.

Changing an educational curriculum can be a challenge and the involvement of all stakeholders is an essential component in successful curriculum revision. Redesigning the entire curriculum was a demanding journey that required significant commitment and effort by all major constituencies. A rigorous faculty development effort was necessary to train the faculty and staff in this major curriculum reform. It was critical to develop a collaborative curriculum planning and development process encompassing leadership and communication. Continued planning and refining of the program are critical as well as faculty development and training in the current curriculum. In addition, the impact of course redesign on the educational experience of students needs to be carefully monitored as a part of ongoing review and adjustment of the curriculum.

\section{References}

1. Crawford JM, Adami G, Johnson BR, G William Knight, Kent Knoernschild, et al. (2007) Curriculum restructuring at a North American dental school: rationale for change. J Dent Educ 71(4): 524-531.

2. Ryder MI, Sargent P, Perry D (2008) Evolution and revolution: the curriculum reform process at UCSF. J Dent Educ 72(12):1516-1530.

3. Sklar DP (2018) Implementing curriculum change: choosing strategies, overcoming resistance, and embracing values. Academic Medicine 93(10): 1417-1419.

4. Burk-Rafel J, Harris KB, Heath J, Milliron A, Savage DJ, et al. (2020) Students as catalysts for curricular innovation: a change management framework. Medical Teacher 42(5): 572-577.

5. Pyle MA (2012) New models of dental education and curricular change: their potential impact on dental education. J Dent Educ 76(1): 89-97.

6. Kassebaum DK, Hendricson WD, Taft T, Haden NK (2004) The dental curriculum at North American dental institutions in 2002-03: a survey of current structure, recent innovations, and planned changes. J Dent Educ 68(9): 914-931. 
7. Formicola AJ, Bailit HL, Weintraub JA, Fried JL, Polverini PJ (2018) Advancing dental education in the $21^{\text {st }}$ century: phase 2 report on strategic analysis and recommendations. J Dent Educa 82(10): eS1eS32.

8. Park SE, Timothe P, Nalliah R, Karimbux N, Howell TH (2011) A case completion curriculum for clinical dental education: replacing numerical requirements with patient-based comprehensive care. J Dent Educ 75(11): 1411-1416.
9. Park SE, Susarla H, Nalliah R, Timothe P, Howell TH, et al. (2012) Does a Case Completion Curriculum Influence Student Clinical Productivity? J Dent Educ 76(5): 602-608.

10. Park SE, Howell TH (2015) Patient-centered approaches to clinical education: A five-year reflection. J Dent Educ 79(5): 523-529.

11. Park SE (2021) 10-year follow-up of patient-centered comprehensive care using case completion curriculum. J Dent Educ.

\section{Your next submission with Juniper Publishers} will reach you the below assets

- Quality Editorial service

- Swift Peer Review

- Reprints availability

- E-prints Service

- Manuscript Podcast for convenient understanding

- Global attainment for your research

- Manuscript accessibility in different formats ( Pdf, E-pub, Full Text, Audio)

- Unceasing customer service

Track the below URL for one-step submission https://juniperpublishers.com/online-submission.php 